\title{
DAMPAK KEPESERTAAN BPJS BAGI PEKERJA INFORMAL DI BOGOR
}

\author{
Fredi Andria ${ }^{1}$ dan Nandang Kusnadi ${ }^{2}$ \\ ${ }^{1}$ Program Manajemen Universitas Pakuan, Jl. Pakuan PO Box 45216143 \\ 2Program Studi Ilmu Hukum Universitas Pakuan, Jl. Pakuan PO Box 45216143 \\ E-mail:fredi_andria@yahoo.com, nandkus@yahoo.co.id
}

\begin{abstract}
Health insurance available in Indonesia is still very limited in scope, given to a small proportion of the Population of Beneficiaries (PBI) and formal workers. This is also the case in the Bogor region, whereas the informal sector population in Bogor dominates more than $70 \%$. The participation of the informal sector population in Bogor City is still low, reaching only $30 \%$ of the total population. Informal sector workers working in small firms, entrepreneurs in the informal and underemployed or elderly economic sectors, will rely on personal insurance or assistance from close and distant relatives and local communities, resulting in a very limited sustainability of group health insurance. In order to increase membership and coverage of health insurance can be expanded, the groups of informal sector workers in the area of Bogor must be recognizable and at the same time can be distinguished by their characteristics. It is necessary to define various segments of informal sector workers. More specifically, it is necessary to establish the mechanisms of the population engaged in the informal sector to be optimized for their participation in the health insurance program coordinated by the BPJS. Therefore it is necessary to analyze the needs of social health insurance system based on identification of informal workers (case study in Bogor city), so that the impact of health insurance (BPJS) partnership can be constructed for informal sector people.
\end{abstract}

Keywords: BPJS, Health Insurance, Informal Sector, Partnership

\section{ABSTRAK}

Jaminan kesehatan yang tersedia di Indonesia masih sangat terbatas jangkauannya, hanya diberikan kepada sebagian kecil penduduk Penerima Bantuan luran (PBI) dan pekerja formal. Hal ini juga terjadi di wilayah Bogor, padahal penduduk sektor informal di wilayah Bogor mendominasi hingga lebih dari 70\%. Kepesertaan penduduk sektor informal di Kota Bogor masih rendah, hanya mencapai 30\% dari total penduduk. Penduduk sektor informal yang bekerja di perusahaan-perusahaan kecil, wiraswasta di sektor perekonomian informal dan yang menganggur atau telah lanjut usia, akan bergantung pada asuransi pribadi atau bantuan dari keluarga dekat dan jauh serta masyarakat setempat, mengakibatkan keberlanjutan jaminan kesehatan kelompok ini sangat terbatas. Agar kepesertaan meningkat dan cakupan jaminan kesehatan dapat diperluas, maka kelompok-kelompok pekerja sektor informal yang ada di wilayah Bogor harus dapat dikenali keberadaannya dan sekaligus dapat dibedakan karakteristiknya. Maka diperlukan pendefinisian berbagai segmen pekerja sektor informal. Lebih khusus lagi perlu dibangun mekanisme penduduk yang bergerak di sektor informal dapat dioptimalkan keikutsertaannya dalam program jaminan kesehatan yang dikoordinir oleh BPJS. Oleh karena itu perlu analisis kebutuhan sistem jaminan sosial kesehatan berdasarkan identifikasi terhadap pekerja informal (studi kasus di Kota Bogor), sehingga dapat dilihat dampak dari kepesertaan BPJS terhadap penduduk sektor informal.

Kata Kunci: Asuransi Kesehatan, BPJS, Kepesertaan, Sektor Informal

JIMFE (Jurnal Ilmiah Manajemen Fakultas Ekonomi)

Volume 3 No. 1 Tahun 2017, Hal. 1-15 


\section{PENDAHULUAN}

\section{Latar Belakang}

Pemerintah berupaya untuk mengimplementasikan UU Sistem Jaminan Sosial Nasional (SJSN) di Indonesia melalui Dewan Jaminan Sosial Nasional (DJSN) dengan diundangkannya UU No. 24 tahun 2011 tentang Badan Penyelenggara Jaminan Sosial (BPJS). BPJS Kesehatan akan menyelenggarakan program jaminan kesehatan pada 31 Desember 2013, secara resmi akan dicanangkan beroperasi per 1 Januari 2014 (Andria et al. 2013).

Jaminan sosial diprioritaskan kepada hanya sebagian kecil penduduk Indonesia yang mewakili kurang dari $20 \%$ penduduk. Penduduk yang dimaksud meliputi pegawai negeri sipil, sebagian karyawan BUMN, universitas, anggota TNI/POLRI dan sebagian pegawai sipil pertahanan, dan kelompok masyarakat penerima bantuan. Adapun penduduk yang lain, terutama mereka yang bekerja di perusahaan-perusahaan kecil, wiraswasta di sektor ekonomi informal dan yang menganggur atau telah lanjut usia, akan bergantung pada asuransi pribadi atau bantuan dari keluarga dekat/jauh serta masyarakat setempat (Andria et al. 2014).

Wilayah Bogor memiliki kepadatan penduduk yang cukup tinggi yakni 8,7 untuk Kota Bogor dan 16,4 untuk Kabupaten Bogor. Pekerja informal di wilayah Bogor mencapai lebih dari 70\% namun tingkat kepesertaannya masih rendah hanya mencapai $30 \%$. Hal ini dapat mengakibatkan keberlanjutan jaminan kesehatan warga Bogor sangat terbatas. Agar cakupan jaminan kesehatan dapat diperluas dan menjamin tercakupnya seluruh penduduk tanpa terkecuali, maka kelompokkelompok penduduk yang ada di masyarakat harus dapat dikenali keberadaannya dan sekaligus dapat dibedakan karakteristiknya. Untuk hal ini diperlukan pendefinisian masyarakat khususnya masyarakat yang bekerja di bidang informal, sekaligus mencari cara untuk dapat membedakannya. Selanjutnya perlu dibangun model atau formulasi keikutsertaan penduduk yang bergerak di sektor informal dalam program ini, padahal kelompok penduduk ini sangat beragam dan perlu pendefinisian lebih rinci.

Hasil kajian Andria et al. (2013) menunjukkan bahwa hanya $73 \%$ tenaga kerja sektor informal di Indonesia yang menyiapkan dana untuk pengobatan. Sekitar $41,8 \%$ tenaga kerja sektor informal hanya mampu menyediakan dana antara Rp100.000 - Rp500.000 setiap tahunnya untuk pengobatan. Kelompok masyarakat tersebut diperkirakan akan menanggung beban yang berat apabila harus membiayai sendiri pembiayaan jaminan kesehatannya kepada BPJS Kesehatan. Kondisi ini juga menunjukkan bahwa kemampuan masyarakat pekerja informal masih sangat membutuhkan bantuan berupa jaminan kesehatan, yang dapat diformulasikan melalui skema-skema tertentu berdasarkan batasan masing-masing wilayah.

Oleh karena itu, diperlukan suatu kajian yang komprehensif untuk menemukan dampak kepesertaan BPJS bagi pekerja sektor informal, khususnya di Kota Bogor. Kajian ini dapat diperoleh melalui kegiatan pendahuluan yang mencakup identifikasi dan observasi kategori kepada pekerja sektor informal (pekerja bukan penerima upah). Analisis masalah dan kendala yang dihadapi pekerja informal untuk mengikuti program sistem jaminan sosial bidang kesehatan. Analisa bentuk-bentuk pengaduan, keberatan dan keluhan yang dirasakan pekerja informal terkait SJSN. Analisis penanganan dan tindak lanjut oleh pemerintah atas bentuk-bentuk pengaduan. Secara umum kegiatan ini diharapkan dapat menggambarkan dengan luas berbagai masalah dan kendala, serta dampak dari kepesertaan BPJS bagi pekerja informal di Bogor. 


\section{Rumusan Masalah}

Selama ini, di Indonesia telah berjalan berbagai program jaminan sosial yang baru mencakup sebagian kecil saja dari penduduk, yaitu terutama mereka yang bekerja di jenis pekerjaan formal. Sedangkan sebagian besar penduduk, yang memiliki pekerjaan di sektor informal, belum terjangkau oleh program jaminan sosial tersebut. Melalui UU SISN, diharapkan seluruh penduduk Indonesia, baik pekerja formal dan informal atau mereka yang tinggal di perkotaan maupun di pedesaan, dapat dijangkau oleh jaminan sosial.

Sebetulnya, kelompok penduduk pekerja sektor informal ini bukannya tidak memperoleh program-program perlindungan sosial. Berbagai program bantuan sosial, bantuan tunai dan asuransi sosial telah diberikan untuk masyarakat namun seringkali tidak dapat menjangkau sasaran karena berbagai masalah seperti adanya biaya yang harus dikeluarkan oleh calon penerima bantuan. Pada akhirnya kelompok penduduk di atas tetap harus mengandalkan bantuan dari masyarakat di lingkungannya. Keberadaan UU SJSN diharapkan dapat memperbaiki situasi yang kerap terjadi di kelompok masyarakat tersebut.

Pada kegiatan ini dikaji lebih khusus mengenai kelompok pekerja sektor informal di Kota Bogor dan bagaimana caranya agar mereka dapat masuk ke dalam cakupan program jaminan sosial secara keseluruhan, terutama jaminan kesehatan. Berkaitan dengan hal tersebut, target kegiatan ini secara spesifik diarahkan kepada: melakukan identifikasi dan observasi kategori kepada pekerja sektor informal (pekerja bukan penerima upah) dalam program SJSN. Secara umum kegiatan ini diharapkan dapat menggambarkan dengan luas berbagai masalah dan kendala terkait program SJSN khususnya bidang kesehatan yang ditargetkan kepada para pekerja di sektor informal di Kota Bogor, dan bagaimana solusi serta dampak kepesertaan akan BPJS terhadap kehidupan pekerja sektor informal di Kota Bogor.

\section{Tujuan Penelitian}

Tujuan penelitian ini adalah:

1. Mengidentifikasi kelompok masyarakat pekerja sektor informal yang tidak termasuk bagian masyarakat miskin dan tidak mampu di Kota Bogor.

2. Mendeskripsikan informasi penting dalam penyelenggaraan program jaminan kesehatan khususnya masyarakat pekerja sektor informal di Kota Bogor.

3. Mengidentifikasi permasalahan pengembangan jaminan kesehatan bagi masyarakat pekerja sektor informal di Kota Bogor.

4. Mengidentifikasi sumber-sumber dan konsepsi kontribusi pendanaan bagi pelaksanaan jaminan kesehatan khususnya masyarakat pekerja sektor informal di Kota Bogor.

5. Merumuskan alternatif pemecahan masalah serta langkah-langkah dalam pengembangan jaminan kesehatan menuju kepesertaan menyeluruh (universal coverage), khususnya bagi masyarakat pekerja sektor informal di Kota Bogor, dan menganalisis dampak kepesertaan BPJS terhadap kehidupan pekerja sektor informal di Bogor.

\section{Manfaat}

Manfaat dari penelitian ini adalah:

1. Terwujudnya sebuah kajian mengenai variabilitas gambaran rencana penyelenggaraan jaminan kesehatan khusus bagi masyarakat pekerja sektor informal, sehingga dapat diwujudkan berbagai kebijakan dalam rangka sinkronisasi penyelenggaraan program jaminan kesehatan secara nasional. 
2. Dihasilkannya gambaran-gambaran permasalahan dan alternatif solusi pengembangan jaminan kesehatan khusus bagi masyarakat pekerja sektor informal dan terwujudnya strategi pemecahan masalah serta langkahlangkah dalam pengembangan jaminan kesehatan.

3. Tersusunnya sebuah analisis dan kajian mengenai pemetaan kesiapan daerah percontohan dalam rencana pelaksanaan program jaminan sosial bidang kesehatan bagi masyarakat pekerja sektor informal, sehingga menjadi masukan dalam penyusunan kebijakan program jaminan kesehatan nasional.

\section{LANDASAN TEORI}

\section{Jaminan Kesehatan di Beberapa Negara}

Negara-negara berpenghasilan menengah mengalami penuaan penduduk yang cepat, sehingga butuh mekanisme pembiayaan dan penyediaan jaminan kesehatan jangka panjang. Hasil riset di tiga negara (Korea Selatan, Jepang, dan Jerman) yang menggunakan asuransi sosial untuk biayai perawatan medis, telah mengembangkan sistem asuransi perawatan jangka panjang (long term care insurance/LTCI). Permasalahan muncul pada generator pendapatan, manfaat desa ini dan kelayakan. Pengembangan skema LTCI lebih awal sangat penting untuk dibangun, sebelum penuaan dan pendapatan substansial menjadi masalah yang signifikan. Salah satu pendekatan untuk memulai sistem ini adalah dengan paket manfaat terbatas, aturan kelayakan ketat dan memperluas program LTCl (Rhee et al. 2015).

$$
\text { Shafie dan Hasalli }
$$
mengusulkan konsep volunteer health care insurance $(\mathrm{VHCl})$ yang diujikan di negara bagian Penang Malaysia. Hasil penelitian menunjukkan bahwa lebih dari $63,1 \%$ responden bersedia untuk bergabung dan berkontribusi dalam skema ini. Besarnya iuran yang disepakati adalah sebesar $\$ 114,38$ per bulan per rumah tangga. Penelitian ini mencakup penduduk dengan ragam etnis, tingkat pendidikan, pendapatan bulanan rumah tangga, adanya penyakit kronis dan adanya cakupan asuransi. Keseriusan dukungan pemerintah dalam manajerial teknis, jaminan keuangan, informasi tentang biaya penyakit, transparansi dan tawaran paket manfaat yang jelas merupakan faktor yang akan merealisasi sistem sehingga dapat berkelanjutan.

Jaminan kesehatan untuk masyarakat sektor informal di Kamboja diulas melalui dokumen kebijakan dan wawancara menggunakan 18 pertanyaan semiterstruktur dengan pemerintah, nonpemerintah dan pejabat terkait. Data dianalisis menggunakan penilaian organisasi untuk membangun framework peningkatan dan penguatan pembiayaan kesehatan. Telah ditemukan konsep yang kurang signifikan terkait dengan kelembagaan, masalah organisasi dan pembiayaan kesehatan. Hal ini mengakibatkan fragmentasi dan terbatasnya pelaksanaan skema perlindungan kesehatan sosial, termasuk dana ekuitas kesehatan, asuransi kesehatan berbasis masyarakat, voucher dan lain-lain. Pengaturan kelembagaan dan organisasi yang tepat, efektif untuk perlindungan kesehatan sosial di sektor informal di negara berkembang (Annear et al. 2013).

Pengalaman Gerakan Kota Sehat, menjadi inspirasi bagi Municipal dalam mengintegrasikan kebijakan lintas sektoral dan memberdayakan masyarakat sipil, agar mampu ke luar dari kemiskinan termasuk dalam upaya peningkatan jaminan kesehatan (Henriques 2013). Kebutuhan akan inovasi sosial belum banyak diimplementasi, sehingga orientasi anti-kemiskinan masih berupa slogan. Pergeseran paradigma akan 
kebutuhan kesehatan menjadi faktor penting untuk perencanaan pengembangan wilayah.

Fitriati et al. (2013) mengusulkan pengembangan model kolaborasi quantotuple model helix untuk persiapan operasional BPJS. Model tersebut merupakan sinergitas 6 pemangku kepentingan demi mensukseskan implementasi jaminan sosial kesehatan. Pemangku kepentingan yang dimaksud mencakup Pemerintah (Presiden), perusahaan (BPJS Asuransi Kesehatan dan BPJS untuk Perlindungan Buruh), ulama, Dewan Pembina BPJS. Strategi transformasi sistem dimulai dengan operasional BPJS untuk asuransi kesehatan. Ada tiga strategi yang ditawarkan: inisiatif sektoral, harmonisasi kepentingan, dan penegakan hukum. Penelitian mencakup pengamatan kondisi sosial menggunakan metode deskriptif analitik, sehingga masih mengandung kekurangan. Oleh karena itu perlu mengembangkan teknik kualitatifkuantitatif atas aspek transformasi BPJS, dukungan kebijakan fiskal dan kemampuan keuangan negara untuk mendukung transformasi.

Pengujian atas dampak jaminan kesehatan telah dilakukan oleh Rolindrawan et al. (2015). Metode analisis yang digunakan adalah analisis deskriptif dan metode inferensial melalui pemeriksaan distribusi BPJS Kesehatan untuk PBI miskin dan hampir miskin di Indonesia. Hasil utama menunjukkan adanya kecenderungan $\mathrm{PBI}$ miskin dan hampir miskin dalam penggunaan fasilitas kesehatan publik dan swasta untuk rawat jalan dan rawat inap. Namun terindikasi ada kebocoran dalam skema ini, sehingga pemerintah dan BPJS perlu mekanisme kontrol yang lebih ketat. Pelaksanaan BPJS Kesehatan PBI pada tahun pertama berhasil mengangkat masyarakat miskin dan hampir miskin untuk memilih fasilitas rawat jalan di rumah sakit swasta/dokter/klinik dibandingkan dengan fasilitas lainnya. Hasil ini menunjukkan kebalikannya dalam pelaksanaan Jamkesmas. Populasi yang tidak diasuransikan memiliki kecenderungan yang lebih tinggi memilih fasilitas kesehatan swasta dibandingkan dengan rawat jalan tertutup oleh Jamkesmas. Kecenderungan untuk memanfaatkan rumah sakit swasta untuk rawat inap dari fasilitas lain bagi penduduk yang dicakup oleh BPJS Kesehatan PBI lebih besar dari populasi yang tidak diasuransikan. Program BPJS Kesehatan telah mampu meningkatkan para lansia untuk cenderung memilih fasilitas rawat inap di rumah sakit swasta dibandingkan dengan fasilitas lainnya.

Pengalaman mendesain kebijakan sistem pembiayaan kesehatan berbasis pada pengambil keputusan untuk mengatasi kesulitan dana dan memberikan perawatan medis Balkan Barat menunjukkan bahwa kesadaran atas biaya kesehatan perlahanlahan berkembang pada manajemen regional, akademik dan masyarakat industri. Restrukturisasi pasca-sosialis membawa banyak perubahan pada pola sistem pembiayaan kesehatan dan manajemen sistemnya. Walaupun masih ada kendala di antaranya ketidaksetaraan sosial kesulitan akses kesehatan masih tumbuh di seluruh wilayah. Kendala lain mencakup pembangunan tidak merata menyebabkan kesulitan dalam merealisasi kebijakan. Lembaga-lembaga utama yang terkait sebagai pengambil keputusan diantaranya adalah Kementerian Nasional Kesehatan, Lembaga Dana Asuransi Kesehatan, dan Asosiasi Profesional (Jacovijevic, 2012).

Pada sisi lain Stepurko (2015) menyoroti permasalahan mendasar tentang perilaku hadiah dan suap atau pembayaran informal untuk pelayanan kesehatan di negara berkembang Eropa Timur, sebagai akibat kegagalan negara dalam menyediakan jaminan kesehatan yang transparan. Studi kasus di Lithuania, Ukraina dan Polandia menunjukkan bahwa pembayaran tidak resmi yang lebih mahal pada rawat inap, 
disebabkan oleh gagalnya sistem jaminan kesehatan yang dibangun oleh negara, sehingga ketersediaan sarana prasarana kesehatan menjadi barang yang sangat mahal. Hal ini mengakibatkan perilaku korupsi yang semakin meningkat.

\section{Masyarakat Sektor Informal}

Rothenberg et al. (2016) mengusulkan teori tentang terciptanya masyarakat sektor informal di Indonesia, serta identifikasi karakteristiknya dalam menghadapi persaingan ekonomi global. Data yang digunakan berasal dari survey nasional mencakup para pelaku Usaha Mikro Kecil Menengah (UMKM). Ada sedikit bukti yang mendukung teori bahwa biaya pendaftaran yang tinggi adalah penghalang utama untuk perusahaan meninggalkan sektor informal. Perusahaan informal di Indonesia cenderung berbeda dari perusahaan-perusahaan formal dalam cara operasionalnya, ukuran, upah karyawan, produktivitas tenaga kerja yang rendah, serta jangkauan pasar terbatas. Karakteristik ini tidak konsisten dengan ide 'Biaya pendaftaran yang mencegah perusahaan-perusahaan informal melakukan formalisasi usahanya'. Metode analisa deskriptif dan survey kualitatif menjadikan hasil penelitian lebih optimal melalui kajian yang komprehensif.

Penilaian biaya kesehatan terkait industri informal yang dilakukan melalui kuesioner yang berisi informasi dasar dari responden dan rumah tangga anggota, ekonomi dan penilaian kerja telah dilakukan oleh Nastiti et al. (2012). Berbagai jenis pekerjaan yang disurvei, populasi sasaran, bias dari pekerjaan, biaya non-occupational dan rumah tangga, pengeluaran individu, dan validasi metode merupakan cakupan riset ini. Riset ini berfungsi sebagai referensi kebijakan - alat untuk meningkatkan kesejahteraan pekerja informal dengan memanfaatkan survei tenaga kerja nasional. Sektor informal sebagian besar memberikan kontribusi terhadap perekonomian negara-negara berkembang seperti Indonesia. Kondisi sektor ini tidak resmi diakui dan jarang dikontrol. Pendapatan stabil, kondisi kerja yang buruk, jam kerja yang tidak diatur. Bahaya keselamatan kerja menimbulkan ancaman serius terhadap kesejahteraan para pekerja, yang tidak dilindungi secara formal. Riset ini dapat jadi alat penilaian dalam memprediksi biaya kesehatan terkait kecelakaan dan kecelakaan kerja di sektor informal. Kekurangan riset ini harus dapat meminimalkan bias atas desain kuesioner. Riset ini juga berguna untuk meningkatkan survei tenaga kerja nasional, dengan memasukkan elemen biaya kesehatan dan keselamatan kerja.

Menurut ILO (2002) ekonomi informal terdiri dari unit-unit ekonomi yang termarjinalisasi dan pekerja-pekerja yang memiliki karakteristik: mengalami defisit dalam pekerjaan yang layak, defisit dalam hal standar perburuhan, defisit dalam hal produktivitas dan kualitas pekerjaan, defisit dalam hal perlindungan sosial dan defisit dalam hal organisasi dan hak suara. Dengan mengurangi defisit yang dimiliki oleh ekonomi informal, diharapkan akan dapat meningkatkan gerakan ke arah kegiatankegiatan yang diakui, terlindungi dan formal di dalam kerangka perekonomian utama dan yang memenuhi peraturan.

Meskipun tidak ada konsensus khusus mengenai definisi sektor informal, perngertian sektor informal ini sering dikaitkan dengan dikotomi sektor formalinformal. ILO (2002) mengidentifikasi sedikitnya tujuh karakter yang membedakan kedua sektor tersebut yaitu: kemudahan untuk masuk, kemudahan untuk mendapatkan bahan baku, sifat kepemilikan, skala kegiatan, penggunaan tenaga kerja dan teknologi, tuntutan keahlian, serta deregulasi dan kompetisi pasar. Sementara itu, Becker 
(2004) mengemukakan bahwa secara umum ekonomi informal adalah bagian dari ekonomi pasar yang tidak punya aturan dan tidak formal, yang memproduksi barang dan jasa untuk dijual atau untuk memperoleh pendapatan lain. Lebih lanjut disebutkan bahwa perekonomian informal sebagian besar memiliki karakteristik:

1. Persyaratan yang rendah, dalam hal modal dan kualifikasi profesional, untuk masuk dalam sektor tersebut.

2. Beroperasi pada skala kecil.

3. Keterampilan yang diperlukan pada umumnya diperoleh dari luar sekolah formal.

4. Metode produksi dan teknologi yang digunakan adalah yang labour intensive.

Lebih lanjut Becker (2004) mengatakan bahwa berdasarkan atas kategori ketenagakerjaan, ekonomi informal dapat digambarkan melalui kategori jenis pekerjaan sebagai berikut:

1. Pekerja mandiri (self-employed), contohnya adalah own-account worker, pemimpin usaha keluarga dan pekerja keluarga yang tidak dibayar.

2. Pekerja yang bergaji, contohnya pegawai perusahaan informal, pekerja tidak tetap tanpa majikan yang tetap, pekerja rumahan, pembantu RT yang dibayar, pekerja sementara dan paruh waktu, dan pekerja yang tidak terdaftar.

3. Majikan, contohnya pemilik perusahaan dan pemilik yang menjalankan usaha informal.

Sementara itu berdasarkan atas lokasi pelaku ekonomi informal, Becker (2004), membaginya atas kategori-kategori:

1. Pekerja yang bekerja di rumah (homebased worker) :

a. Pekerja rumah yang tidak bebas:

Bekerja di rumah, di luar perusahaan yang membeli barang produksi mereka. Dengan perjanjian sebelumnya, sepakat untuk men-supply barang atau jasa ke perusahaan tertentu. Memperoleh pendapatan melalui pembayaran trehadap apa yang diproduksi. Tidak mempekerjakan pekerja secara teratur.

b. Pekerja rumah yang bebas, adalah mereka yang bekerja di rumah dan menyalurkan hasil produksi dan jasanya kepada pembeli yang prospektif. Karakteristik mereka adalah sebagai pekerja mandiri dan memiliki sifat dari pekerja account workers.

2. Pedagang asongan jalanan dan pedagang kaki lima di pinggir jalan.

3. Pekerja musiman atau pekerja sementara di lokasi sekitar bangunan atau jalan yang sedang dikerjakan.

4. Mereka yang bekerja di antara jalanan dan rumah, contohnya pemulung.

Pada International Conference of Labour Statisticians - ICLS ke-17 Hussmanns (2003) membuat definisi ekonomi informal berdasarkan unit produksi sebagai berikut: unit usaha yang terlibat dalam produksi barang dan jasa dengan tujuan utama untuk menciptakan kesempatan kerja dan pendapatan bagi orang-orang yang terlibat. Hubungan ketenagakerjaan, jika memang ada, kebanyakan atas dasar pekerjaan tidak tetap, persaudaraan atau hubungan pribadi dan hubungan sosial, dan bukan atas dasar persetujuan kontrak dengan jaminan formal. Selanjutnya konsep ini juga membedakan antara dua sub-kategori dari ekonomi informal, yaitu:

1. Perusahaan keluarga, terdiri dari pekerja mandiri, pekerja keluarga, pekerja magang, dan mereka yang tidak memiliki pegawai tetap.

2. Perusahaan kecil, terdiri dari unit usaha dengan pegawai berjumlah kurang dari 5 sampai dengan 10 orang, dan tidak terdaftar sebagai perusahaan.

Canagarajah dan Sethuraman (2001), dari The Human Development Network, The World Bank, menyatakan bahwa ekonomi informal terdiri dari seluruh kegiatan ekonomi yang berada diluar kerangka 
institusional resmi. Akibatnya, pemerintah hanya memiliki kontrol yang kecil terhadap kualitas dari ketenagakerjaannya. Bahkan seringkali pemerintah pada kenyataannya tidak memiliki data statistik dari kelompok ini.

Di Indonesia, Badan Pusat Statistik (BPS) selama ini menggunakan pengertian/definisi mengenai sektor informal berdasarkan kategori dari status pekerjaan dari pekerja. Status pekerjaan adalah kedudukan seseorang dalam melakukan pekerjaan di suatu unit usaha/kegiatan. Seperti diketahui, sejak tahun 2001 BPS membagi status pekerjaan menjadi 7 kategori, yaitu: 1) berusaha sendiri, 2) berusaha dibantu buruh tidak tetap/buruh tak dibayar, 3) berusaha dibantu buruh tetap/buruh dibayar, 4) buruh/ karyawan/pegawai, 5) pekerja bebas di pertanian, 6) pekerja bebas di non pertanian, 7) pekerja tak dibayar.

Dari sekian banyak kategori status pekerjaan, hanya 2 kategori yang dapat disebut sebagai bekerja pada sektor formal, yaitu mereka yang berstatus sebagai buruh/karyawan/pegawai dan mereka yang berstatus sebagai majikan (kategori c dalam daftar kategori di atas). Selebihnya adalah mereka yang termasuk dalam sektor informal, yaitu mereka yang berusaha sendiri, berusaha dibantu buruh tidak tetap/buruh tak dibayar, pekerja bebas di pertanian, pekerja bebas di non pertanian, dan pekerja tak dibayar (termasuk pekerja keluarga).

Kendala sosial yang dihadapi dalam implementasi jaminan sosial ketenagakerjaan untuk pekerja informal diantaranya adalah faktor indown (rendahnya tingkat pendidikan, akses informasi dan ekonomi) serta faktor eksternal yang mencakup penanganan pihak birokrat. Perluasan kepesertaan jaminan sosial untuk pekerja informal dapat didorong melalui pembenahan birokrasi dan pembinaan usaha mikro kecil. Pembenahan bidang pendidikan dan informasi melalui kelurahan atau kantor desa (dianggap lebih mudah menjangkau masyarakat), menjadi faktor penguat utama dalam capaian target (Triyono dan Soewartoyo 2013).

\section{Penelitian Terdahulu}

Penelitian ini didasari oleh keterlibatan Ketua Tim Peneliti dalam kegiatan penelitian yang didanai DJSN terkait kesiapan pemda menuju UHC (Thaheer et al. 2011) dan pemetaan Pemda dalam mendukung persiapan BPJS menuju UHC (Andria et al. 2012), dan Kemenkokesra RI yang menghasilkan riset tentang kebijakan format Jamkesda dalam UU BPJS (Andria et al. 2013). Implementasi atas ketiga riset terdahulu dan didukung oleh riset-riset khusus lain terkait jaminan sosial maupun fokus ke jaminan kesehatan yang relevan Triyono dan Soewartoyo (2012) dan Purwandari dan Maharani (2015) khususnya untuk studi kasus di Kota Bogor.

\section{METODE PENELITIAN}

Tahapan penelitian secara lengkap adalah sebagai berikut:

1. Perumusan dan identifikasi awal masalah jaminan kesehatan untuk pekerja sektor informal di Kota Bogor akan dilakukan melalui studi literatur dan analisis datadata sekunder.

2. Perencanaan lokasi penelitian ini akan dilakukan di Kota Bogor. Wilayah ini dipilih karena telah ada kesepakatan kerja antar Universitas dengan Pemda terkait dengan kegiatan penelitian dan pengabdian. Alasan lain mengingat area jangkauan yang disesuaikan dengan dana penelitian. Pembagian daerah survey akan dilakukan untuk 6 Kecamatan yaitu Timur, Barat, Utara, Selatan, Tengah dan Tanah Sareal Kota Bogor.

Penyusunan kuesioner akan dilakukan secara bertahap, karena 
meliputi kuesioner untuk para pekerja sektor informal (a) dan kuesioner untuk pemangku kepentingan (b). Kuesioner (a) akan disusun melalui model pertanyaan tertutup sehingga lebih efektif dalam proses pengolahan dan analisis data. Kueosioner (b) akan didominasi oleh pertanyaan tertutup namun tetap ada sebagian kecil berupa pertanyaan semi terbuka.

3. Penentuan teknik sampling diawali dengan penentuan populasi yakni para pekerja informal yang menjadi penerima jaminan sosial kesehatan di Kota Bogor. Pengambilan sample dilakukan dengan cara sampling bertingkat (multi stage sampling). Tahap awal, sample diambil dengan metode area sampling (sampling daerah) dengan maksud untuk menentukan daerah-daerah yang menjadi obyek penelitian. Husein (2003) menyatakan bahwa area sampling sesuai untuk penelitian dimana melibatkan populasi yang besar dan tersebar di daerah yang luas. Generalisasi yang diperoleh berdasarkan penelitian daerahdaerah tertentu dapat diterima sebagai pemberlakuan bagi daerah-daerah di luar sampel. Dengan area sampling terpilih yaitu Kota Bogor dan akan dipecah ke dalam 6 (enam) kecamatan yaitu : Timur, Barat, Utara, Selatan, Tengah dan Tanah Sareal.

Tahapan kedua, setelah representasi area dari masing-masing wilayah ditentukan, kemudian dipilih responden dalam setiap area untuk melalui purposive sampling. Metode ini menurut Husein (2003) dilakukan dengan cara mengambil orang-orang yang terpilih oleh peneliti menurut pertimbangan atau ciri-ciri khusus yang dimiliki oleh sampel itu. Berdasarkan metode purposive sampling ini, diperoleh kriteria responden sebagai berikut: Pedagang Kecil (mencakup pedagang asongan/jalanan, pedagang kaki lima, tukang jamu gendong, tukang kelontong, pedagang sembako/pedagang pasar, penjaja makanan keliling, penjual rokok pinggir jalan dan lainnya); Penjual Jasa, (mencakup penjahit/tukang jahit, pemulung, tukang ojek, tukang becak, penata parker, tukang tambal ban, tukang urut/pijat, pengumpul sampah dan lainnya); Buruh Tani, Buruh Ternak, dan lainnya. Jumlah total sampel dalam kegiatan ini adalah 100 (seratus) responden. Jumlah ini dipecah ke dalam 6 (enam) kecamatan tadi, dan masingmasing area dipilih sebanyak $10-20$ orang responden.

4. Observasi dan survey lapangan akan dilakukan dengan oleh mahasiswa (enumerator) sebanyak 10 orang, yang akan disebar ke 6 kecamatan survey untuk tiap wilayah dan disupervisi oleh tim peneliti. Enumerator diberi pelatihan singkat terkait seluruh konten dan substansi kuesioner, tata cara penggalian informasi dan etika survey.

5. Pengolahan data akan dilakukan dengan aplikasi Statistical Package for Social Sciences (SPSS) versi 21.0. Analisa data akan dilakukan melalui : a) Tabulasi frekuensi (Proses penghitungan frekuensi yang terbilang atas jawaban responden dalam kuesioner ke dalam masing-masing kategori disebut dengan tabulasi); b) Tabulasi Silang (Teknik pengolahan untuk membandingkan atau melihat hubungan antara dua variabel atau lebih. Dalam tabulasi silang biasanya dihitung persentase responden untuk setiap kelompok agar mudah dilihat hubungan antara dua variabel. Variabel terikat (dependent variable) disusun pada bagian baris, sedangkan variabel bebas (independent variable) disusun pada bagian kolom; c) Analisa Jaring Laba-laba (Metode analisis kuantitatif sederhana yang digunakan untuk memetakan 
perbandingan berbagai variabel atau parameter penilaian dalam bentuk grafis berbentuk jaring laba-laba. Pemetaan dilakukan dengan menggunakan pengukuran variabel/parameter dengan skala ordinal).

\section{HASIL DAN PEMBAHASAN}

Jumlah sampel responden pekerja sektor informal dari 6 kecamatan adalah sebanyak 100 orang, yang terdiri dari yang terdiri dari 20 orang dari Kecamatan Bogor Timur, 20 orang dari Kecamatan Bogot Barat, 20 orang dari Kecamatan Bogor Utara, 20 orang dari Kecamatan Bogor Selatan, 10 orang dari Kecamatan Bogor Tengah dan 10 orang Kecamatan Tanah Sareal. Jumlah responden sebanyak 100 orang responden ini adalah jumlah sampel yang dianggap valid, reliable dan yang kembali dalam rentang waktu yang ditolerir dari sebanyak 125 lembar kuesioner yang disebar di 6 wilayah target. Data sampel yang bisa kembali, valid dan reliable ini selanjutnya masuk pada tahap pengolahan lanjutan.

Berdasarkan hasil survey ke 6 wilayah target diperoleh informasi awal mengenai karakteristik responden seperti yang dijelaskan secara detail di bawah, dengan mempergunakan software SPSS versi 21.0. Sebaran karakteristik yang dijelaskan ini melingkupi: jenis kelamin, status, usia, profesi, jumlah tanggungan, pendidikan, pendapatan dan kepemilikan aset, yang merupakan karakteristik gabungan untuk ke 6 wilayah survey.

Berdasarkan jumlah 100 orang responden pekerja sektor informal yang disurvey, sebanyak 69\% (69 orang) berjenis kelamin laki-laki, dan sebanyak 31\% (31 orang) adalah berjenis kelamin perempuan (Tabel 1). Sebagian besar dari responden ini
(83\%) atau sebanyak 83 orang berstatus menikah (Tabel 2).

Tabel 1. Sebaran Responden Menurut Jenis Kelamin

\begin{tabular}{|l|c|c|}
\hline \multicolumn{1}{|c|}{ Jenis Kelamin } & Frekuensi & $\%$ \\
\hline Laki-laki & 69 & $69 \%$ \\
\hline Perempuan & 31 & $31 \%$ \\
\hline Total & 100 & $100 \%$ \\
\hline
\end{tabular}

Sumber : Diolah dari data primer

Tabel 2. Sebaran Responden Menurut Status

\begin{tabular}{|l|c|c|}
\hline \multicolumn{1}{|c|}{ Status } & Frekuensi & $\%$ \\
\hline Menikah & 83 & $83 \%$ \\
\hline $\begin{array}{l}\text { Belum } \\
\text { Menikah }\end{array}$ & 8 & $8 \%$ \\
\hline $\begin{array}{l}\text { Pernah } \\
\text { Menikah } \\
\text { (Janda/Du } \\
\text { da) }\end{array}$ & 9 & $9 \%$ \\
\hline Total & 100 & $100 \%$ \\
\hline
\end{tabular}

Sumber : Diolah dari data primer

Tabel 3. Sebaran Responden Menurut Profesi

\begin{tabular}{|l|c|c|}
\hline \multicolumn{1}{|c|}{ Profesi } & Frek & $\%$ \\
\hline Pedagang Asongan & 4 & $4 \%$ \\
\hline Pedagang Kaki Lima & 14 & $14 \%$ \\
\hline Pedagang Kelontong & 16 & $16 \%$ \\
\hline Pemulung & 6 & $6 \%$ \\
\hline Tukang Ojek & 5 & $5 \%$ \\
\hline Tukang Becak & 2 & $2 \%$ \\
\hline Penata Parkir & 4 & $4 \%$ \\
\hline Tukang Tambal Ban & 7 & $7 \%$ \\
\hline Pedagang Keliling & 16 & $16 \%$ \\
\hline Tukang Jahit & 5 & $5 \%$ \\
\hline Salon & 1 & $1 \%$ \\
\hline Pemilik Kontrakan & 2 & $2 \%$ \\
\hline Petugas Kebersihan & 1 & $1 \%$ \\
\hline Penjual Minuman & 6 & $6 \%$ \\
\hline Jasa Foto Copy & 1 & $1 \%$ \\
\hline Penjual Bensin Eceran & 1 & $1 \%$ \\
\hline Jasa Service & 3 & $3 \%$ \\
\hline
\end{tabular}

JIMFE (Jurnal Ilmiah Manajemen Fakultas Ekonomi) Volume 3 No. 1 Tahun 2017, Hal. 1-15 


\begin{tabular}{||l|c|c|}
\hline Penjual Makanan & 4 & $4 \%$ \\
\hline Penjual Baju & 1 & $1 \%$ \\
\hline Barbershop & 1 & $1 \%$ \\
\hline Total & 100 & $100 \%$ \\
\hline
\end{tabular}

Sumber : Diolah dari data primer

Dari 100 orang responden yang di survey, ada 3 profesi utama yang yang ditemukan, yakni kategori pedagang keliling $(16 \%)$, pedagang kelontong (16\%) dan pedagang kaki lima (14\%). Selanjutnya jenis profesi responden lainnya yang bisa dihitung secara signifikan adalah tukang tambal ban (7\%), penjual minuman (6\%), pemulung (6\%), tukang ojek (5\%), penata parkir, penjual makanan dan pedagang asongan yang jumlah relatifnya masing-masing $4 \%$ dari total responden yang di survey. Sisa profesi responden lainnya tersebar ke dalam jenis lainnya seperti: tukang becak, salon, barbershop, tukang jahit, pemilik kontrakan dan lain sebagainya. Profesi responden ini secara jelas di tampilkan pada Tabel 3 di atas.

Berdasarkan kategori jumlah tanggungan keluarga responden di 6 kecamatan, para responden mengaku memiliki tanggungan keluarga yang cukup banyak. Sebanyak 47 responden mengaku memiliki tanggung keluarga sebanyak 2 - 3 orang. Namun untuk beberapa responden di beberapa wilayah Kota Bogor, memiliki jumlah tanggungan $>=3$ orang, secara total ada sebesar $24 \%$ (24 orang responden). Hanya sebagian kecil saja dari responden (13 orang) yang tidak memiliki jumlah tanggungan (Tabel 6).

Secara prinsip, dengan cukup banyaknya jumlah tanggungan keluarga responden, (hasil survey: dominan tanggungan 2-3 orang, bahkan ada yang lebih dari 3 orang) maka secara otomatis responden yang bertindak sebagai pencari nafkah memiliki beban yang berat dalam upaya menghidupi keluarganya. Wajar akhirnya bahwa keluarga responden bisa berada pada taraf hidup kelas bawah, dan masuk dalam kategori miskin/tidak mampu (kategori Penerima Bantuan luran).

Tabel 4. Sebaran Responden Menurut Jumlah Tanggungan Keluarga

\begin{tabular}{|l|c|c|}
\hline Tanggungan Keluarga & Frek & $\%$ \\
\hline 1 Orang & 16 & $16 \%$ \\
\hline 2 Orang & 25 & $25 \%$ \\
\hline 3 Orang & 22 & $22 \%$ \\
\hline$>3$ Orang & 24 & $24 \%$ \\
\hline Tidak ada & 13 & $13 \%$ \\
\hline Total & 100 & $100 \%$ \\
\hline
\end{tabular}

Sumber : Diolah dari data primer

Profil selanjutnya terkait dengan tingkat pendidikan responden. Berdasarkan data pada Tabel 7 di bawah, diketahui bahwa sebagian besar tingkat pendidikan responden di 6 wilayah survey hanya sampai pada tingkat SLTA (36\%). Namun jumlah responden yang memiliki tingkat pendidikan SD dan SLTP juga cukup banyak, yaitu 33\% dan $23 \%$, namun ada sebagian dari mereka yang tidak menuntaskan pendidikannya. Jika dilihat dari hasil sebaran tingkat pendidikan ini, bisa disimpulkan bahwa dominan responden memiliki pendidikan yang cukup baik (minimal SLTA), walaupun sebagian yang lain sedikit lebih rendah tingkat pendidikannya.

Tabel 5. Sebaran Responden Menurut Tingkat Pendidikan

\begin{tabular}{|l|c|c|}
\hline \multicolumn{1}{|c|}{ Tingkat Pendidikan } & FreK & $\%$ \\
\hline Tidak Pernah Sekolah & 4 & $4 \%$ \\
\hline SD & 33 & $33 \%$ \\
\hline SLTP & 23 & $23 \%$ \\
\hline SLTA & 36 & $36 \%$ \\
\hline Lainnya & 4 & $4 \%$ \\
\hline Total & 100 & $100 \%$ \\
\hline
\end{tabular}

Sumber : Diolah dari data primer

Jika dilihat pada Tabel 6, tingkat pendapatan responden para pekerja sektor informal ini dapat dikelompokkan menjadi tiga kategori. Kategori pertama adalah kelompok responden dengan pendapat paling rendah yaitu $<=$ Rp500.000. Jumlah

JIMFE (Jurnal Ilmiah Manajemen Fakultas Ekonomi)

Volume 3 No. 1 Tahun 2017, Hal. 1-15 
responden yang masuk kategori ini sangatlah kecil, yaitu hanya 8 orang $(8 \%)$ dari total keseluruhan responden. Kategori pendapatan kedua memiliki pendapatan antara Rp500.001 - Rp2.500.000, jumlah responden yang masuk kelompok ini cukup bervariasi dan jumlahnya menjadi dominan jika dikumulatifkan, yaitu sebesar 67 orang (67\%).

Tabel 6. Sebaran Responden Menurut Tingkat Pendapatan

\begin{tabular}{|l|c|c|}
\hline \multicolumn{1}{|c|}{ Pendapatan (ribu) } & Frek & $\%$ \\
\hline$<=$ Rp. 500 & 8 & $8 \%$ \\
\hline Rp. $501-$ Rp. 1.000 & 19 & $19 \%$ \\
\hline Rp. $1.001-$ Rp. 1.500 & 14 & $14 \%$ \\
\hline Rp. $1.501-$ Rp. 2.000. & 13 & $13 \%$ \\
\hline Rp. $2.001-$ Rp. 2.500 & 21 & $21 \%$ \\
\hline >= Rp. 2.500 & 25 & $25 \%$ \\
\hline Total & 100 & 100,0 \\
\hline
\end{tabular}

Sumber : Diolah dari data primer

Kategori terakhir adalah responden yang memiliki tingkat pendapatan lebih dari Rp2.500.000, dengan jumlah responden yang cukup besar. Jika kita lihat detail sebaran khusus untuk pendapatan responden kelompok ketiga ini (pendapatan di atas Rp2.500.000), maka Tabel 6 dengan jelas menyajikan bahwa ada sebagian responden yang memiliki pendapatan per bulan yang cukup lumayan, bahkan bisa dikategorikan sebagai mampu.

Berdasarkan hasil survey lapangan, diperoleh informasi bahwa setiap bulan terdapat $46 \%$ (46 orang) dari total responden yang dapat menyisihkan sebagian pendapatannya untuk ditabung (Tabel 7). Namun ada juga sebanyak $54 \%$ yang mengaku bahwa mereka tidak mampu untuk menyisihkan pendapatan yang mereka peroleh dalam sebulan untuk ditabungkan.

Tabel 7. Sebaran Responden Menurut Ada/Tidaknya Tabungan

\begin{tabular}{|c|c|c|}
\hline Tabungan & FreK & $\%$ \\
\hline
\end{tabular}

\begin{tabular}{||c|c|c|}
\hline Tidak ada & 54 & $54 \%$ \\
\hline Ada & 46 & $46 \%$ \\
\hline Total & 100 & $100 \%$ \\
\hline
\end{tabular}

Sumber : Diolah dari data primer

Bagi mereka yang mampu untuk menabung, jika ditelisik lebih detail, besarnya tabungan yang mampu mereka sisihkan sangat bervariasi. Misalnya, sebanyak 32\% responden (15 dari 46 orang responden yang mampu menabung) menyisihkan sebesar <= Rp100.000 dari total pendapatannya untuk ditabung.

Tabel 8. Sebaran Responden Menurut Jumlah Tabungan per Bulan

\begin{tabular}{|l|c|c|}
\hline \multicolumn{1}{|c|}{ Besar Tabungan } & Frek & $\%$ \\
\hline$<=$ Rp. 100.000 & 15 & $32.6 \%$ \\
\hline Rp. 200.000 & 9 & $19.6 \%$ \\
\hline Rp. 300.000 & 7 & $15.2 \%$ \\
\hline Rp. 500.000 & 7 & $15.2 \%$ \\
\hline$>$ Rp. 500.001 & 8 & $17.4 \%$ \\
\hline Total & 46 & $100 \%$ \\
\hline
\end{tabular}

Sumber : Diolah dari data primer

Jumlah di atas merupakan jumlah dominan dalam variasi besarnya uang yang mampu ditabungkan. Namun disamping itu, ada responden yang mampu menyisihkan uang untuk tabungan > Rp500.000, sebanyak $17,4 \%$ responden (atau 8 dari 46 orang yg mampu menabung). Dan ada pula sebanyak $19,6 \%$ dari 46 orang responden yang mampu menabung, bisa menyisihkan pendapatannya setiap bulan senilai Rp200.000. Bahkan dalam jumlah yang memang relatif sedikit (15,2\% atau 7 orang responden) mampu menyisihkan pendapatan bulanannya untuk menabung dalam kisaran angka Rp300.000 dan Rp500.000. Secara jelas hal ini dipaparkan dalam Tabel 8 di atas.

Selain kemampuan responden dalam menyisihkan dana untuk ditabungkan, dalam survey lapang juga ditanyakan apakah responden mampu menyisihkan dana khusus untuk antisipasi jika mengalami sakit. Karena secara logis, alokasi dana tabungan itu bisa 
ditafsirkan memiliki kemungkinan penggunaan yang lebih luas, dan belum tentu akan dialokasikan untuk tabungan kesehatan (Tabel 11).

Tabel 9. Sebaran Responden Menurut Ada/Tidaknya Dana yang Disisihkan untuk Berjaga-jaga Dikala Sakit

\begin{tabular}{||l|c|c|}
\hline $\begin{array}{c}\text { Dana untuk Jaga- } \\
\text { jaga }\end{array}$ & Frekuensi & $\begin{array}{c}\text { Persenta } \\
\text { se }\end{array}$ \\
\hline Tidak ada & 33 & $33 \%$ \\
\hline Ada & 13 & $13 \%$ \\
\hline Total & 46 & $46 \%$ \\
\hline MissingSystem & 54 & $54 \%$ \\
\hline Total & 100 & $100 \%$ \\
\hline
\end{tabular}

Sumber : Diolah dari data primer

Dari hasil wawancara di lapangan kepada para responden pekerja sektor informal ini, diperoleh informasi bahwa hanya sebanyak $13 \%$ responden (13 orang dari total keseluruhan responden), memiliki dana khusus yang sengaja disisihkan untuk berjaga-jaga untuk keadaan darurat atau berjaga-jaga dikala sakit. Selebihnya responden sama sekali tidak memiliki dana untuk berjaga-jaga dikala sakit, bahkan lebih dari separuh (54\%) responden tidak mau menjawab pertanyaan dimaksud. Besarnya jumlah dana yang mampu di sisihkan untuk dana antisipasi sakit tersebut cukup bervariasi.

\section{KESIMPULAN DAN SARAN Kesimpulan}

Pentingnya investasi yang dikeluarkan dalam kegiatan ini sehingga hasil dari kegiatan ini harus mendatangkan manfaat yang sebesar-besarnya. Oleh karena itulah alasan laporan kemajuan ini kami sampaikan dengan maksud memberikan gambaran progres sementara atas apa yang sedang dilakukan Tim Peneliti. Sehingga diharapkan nantinya hasil yang diperoleh dari pekerjaan ini akan memberikan masukan yang positif bagi pihak DJSN dan pemerintah dalam mengembangkan program jaminan sosial bidang kesehatan dengan sasaran para pekerja di sektor informal, dimana Kota Bogor hanya sebagai salah satu sampel wilayah yang dikaji.

\section{Saran}

Perlu dilakukannya penelitian dengan tema serupa untuk cakupan wilayah dan dengan anggaran yang lebih besar ke depannya. Hal ini bertujuan bahwa kajian dan penelitian mengangkat masalah jaminan kesehatan khususnya untuk pekerja sektor informal ini sangat krusial mengingat besarnya jumlah masyarakat pada sektor ini di Indonesia. Sehingga diperlukan lingkup wilayah sampel yang lebih besar dan lebih banyak, untuk memberikan masukan yang lebih komprehensif kepada pemerintah.

\section{DAFTAR PUSTAKA}

Andria F, Thaheer H, Tosida ET. 2013. Pemetaan pemda dalam mendukung persiapan BPJS kesehatan menuju Universal Health Coverage (UHC). Seminar Hasil Penelitian Bersumber Dana Hibah DJSN, Jakarta, 8 Juni 2013.

Andria F, Thaheer $\mathrm{H}$, Tosida ET, Setyaningsih S, Harsani P. 2014. Kebijakan format Jamkesda dalam UU BPJS. Seminar Hasil Penelitian Bersumber Dana Hibah Kemenkokesra RI, Jakarta 27 November 2014.

Annear PL, Ahmed S, Ros CE, Ir P. 2013. Strengthening Institutional and Organization Capacity for Social Health Protection of the Informal Sector in Lesser-developed Countries: A study of Policy Barriers and Opportunities in Cambodia. Social Science \& Medicine 96(2013):223-231.

http://dx.doi.org/10.1016/j.socscimed.20 13.02.015.

JIMFE (Jurnal Ilmiah Manajemen Fakultas Ekonomi)

Volume 3 No. 1 Tahun 2017, Hal. 1-15 
Becker KF. 2004. The Informal Economy: Fact Finding Study. SIDA. [diunduh 2016 Jan 23]. Tersedia pada : http://www.rrojasdatabank.info/sida.pdf.

Canagarajah S, Sethuraman SV. 2001. Social Protection and the Informal Sector in Developing Countries Challenges and Opportunities. Social Protection Discussion Paper Series No. 0130. [diunduh 2016 Jan 23]. Tersedia pada: http://siteresources.worldbank. org/ SOCIALPROTECTION / Resources / SPDiscussion-papers/ Labor-MarketL130.pdf.

Fitriati R, Rahmayanti KP, Salomo RV. 2012. Critical Review of Triple Helix to QuantoTuple Helix: Lesson Learned from Social Security System Act Implementation. Procedia - Social and Behavioral Sciences 52 (2012):217-225. Doi: 10.1016/j.sbs.pro. 2012.09.458.

Henriques JM. 2013. On Becoming Healthier Communities: Poverty, Territorial Development and Planning. Rev Port Sauude Publica 31(1):58-73. http://dx.doi.org/10.1016/.rpsp.2013.05. 006.

Hussmanns R. 2004. Statistical Definition of Informal Employment: Guidelines Endorsed by the Seventheenth International Conference of Labor Statisticians (2003). $7^{\text {th }}$ Meeting of the Expert Group on Informal Sector Statistics (Delhi Group), New Delhi, 2-4 February 2004. [diunduh 2016 Jan 23]. Tersedia pada: http://ilo.org/public/english/ bureau/stat/download/papers/def.pdf.

ILO. 2002. Decent Work and the Informal Economy: Sixth Item on the Agenda. Report VI. International Labour Conference $90^{\text {th }}$ Session 2002. ISBN 92-2112429-0; ISSN 0074-6681.[diunduh 2016 Jan 23]. Tersedia pada http://www.ilo.org/public/english/ standards/relm/ilc/ilc90/pdf/rep-vi.pdf.
Jakovijevic MB. 2013. Resource Allocation Strategies in Southeastern European Health Policy. Eur J Health Econ 14(2013):153-159. Doi: 10.1007/s10198012-0439-y.

Nastiti A, Prabaharyaka I, Roosmini E, Kunaefi TD. 2012. Health-associated Cost of Urban Informal Industrial Sector : An Assessment Tool. Procedia-Social \& Behavioral Sciences 36(2012):112-122. doi: 10.1016/j.sbspro.2012.03.013.

Purwandari SI, Maharani C. 2015. Analisis Sikap Pekerja Informal Non PBI yang Belum Terdaftar Program Jaminan Kesehatan Nasional di Kabupaten Brebes. UJPH 4 (2):84-91. .[diunduh 2016 Jan 2]. Tersedia pada: http://journal.unnes.ac.id/sju/index.php Lujph.

Rhee JC, Done N, Anderson GF. 2015. Considering Long-term Care Insurance for Middle-income Countries: Comparing South Korea with Japan and Germany. J. Health Policy 119 (2015) 1319-1329. http://dx.doi.org/10.1016/j.healthpol.20 15.06 .00 .

Rolindrawan D. 2015. The impact of BPJS Health Implementation for Poor on the Use of Health Facility. Procedia - Social and Behavioral Sciences 211(2015) 550 559. 2nd Global Conference on Business and Social Science-2015, GCBSS-2015, 1718 September 2015, Bali [ID]. doi: 10.1016/j.sbspro.2015.11.073.

Rothenberg AD, Gaduh A, Burger NE, Chazali C, Tiandraningsih I, Radikun R, Sutera C, Weilant S. 2016. Rethinking Indonesia's Informal Sector. World Dev. 80(2016):96-113. http://dx.doi.org/10.1016/i.worlddev.20 15.11.005.

Shafie AA, Hassali MA. 2013. Willingness to Pay for Voluntary Community-based Health Insurance: Findings from An Exploratory Study in the State of Penang, 
Malaysia. Social Science \& Medicine 96

(2013)

272-276.

http://dx.doi.org/10.1016/j.socscimed.

2013.02.045.

Stepurko T, Pavlova M, Gryga I, Murauskiene

L, Groot W. 2015. Informal Payment for Health Care Service: The Case of Lithuania, Poland and Ukraine. J. Eurasian Studies 6, (2015):46-58. http://dx.doi.org/10.1016/j.euras.2014.1 1.002.

Thaheer H, Andria F. 2012. Kesiapan Pemda Menuju Kepesertaan Menyeluruh Jaminan Kesehatan. Seminar Hasil Penelitian Bersumber Dana Hibah DJSN, 2 Desember 2011.

Triyono, Soewartoyo. 2013. Kendala Kepesertaan Program Jaminan Sosial terhadap Pekerja di Sektor Informal: Studi Kasus di Kota Surabaya. Jurnal Hukum PRIORIS, 3 (3): 28-41. [diunduh 2016 Jan 2]. Tersedia pada: http://lib.law.ugm.ac.id/ojs/index.php/i $\mathrm{hpr/article/view/3557}$

\section{UCAPAN TERIMAKASIH}

1. DRPM Ristekdikti yang telah membiayai kegiatan PDP.

2. LPPM Universitas Pakuan yang telah memotivasi, memberi dukungan dana "in-kind" dan memfasilitasi kegiatan PDP ini mulai dari pengajuan proposal, hingga monitoring dan terus memotivasi untuk keberlanjutan kegiatan seperti ini.

3. Program Studi Manajemen dan FEA Universitas Pakuan, yang telah mendukung kegiatan ini melalui penyediaan dosen-dosen dan mahasiswa yang terlibat dalam kegiatan survey.

JIMFE (Jurnal Ilmiah Manajemen Fakultas Ekonomi)

Volume 3 No. 1 Tahun 2017, Hal. 1-15 